
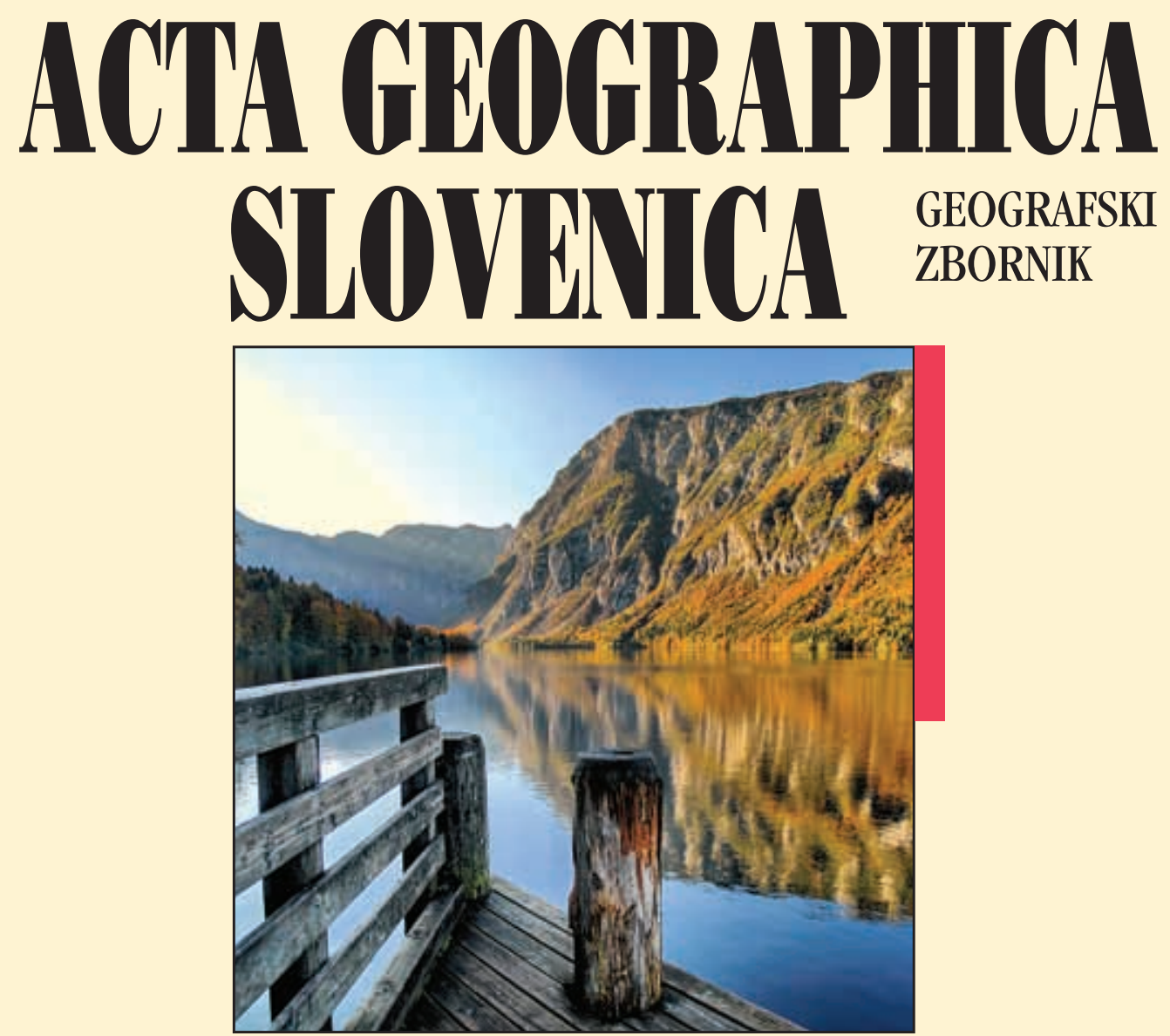

2018

58

2 


\section{ACTA GEOGRAPHICA SLOVENICA GEOGRAFSKI ZBORNIK $58-2 \cdot 2018$}

\section{Contents}

Ivan ČANJEVAC, Danijel OREŠIĆ

Changes in discharge regimes of rivers in Croatia

Jaka PLEČKO, Nejc BEZAK, Marjeta ŠKAPIN RUGELJ, Mojca ŠRAJ

Does it really rain more often on weekends than on weekdays: a case study for Slovenia

Katja VINTAR MALLY

Regional Differences in Slovenia from the Viewpoint of Achieving Europe's Sustainable Development

Petra RUS, Janez NARED, Štefan BOJNEC

Forms, areas, and spatial characteristics of intermunicipal cooperation in the Ljubljana Urban Region

Jadwiga GAŁKA, Anna WARYCH-JURAS

Suburbanization and migration in Polish metropolitan areas during political transition

Ewa SKOWRONEK, Andrzej TUCKI, Edward HUIJBENS, Marta JÓŹWIK

What is the tourist landscape? Aspects and features of the concept

Irene BOLLATI, Emmanuel REYNARD, Davide CAGNIN, Manuela PELFINI The enhancement of cultural landscapes in mountain environments: An artificial channel history (Torrent-Neuf, Canton Valais, Switzerland) and the role of trees as natural archives of water flow changes

Piotr RAŹNIAK, Sławomir DOROCKI, Anna WINIARCZYK-RAŹNIAK

Eastern European cities as command and control centers in a time of economic crisis

Jani KOZINA

Demographic characteristics of creative workers: under-activated development potentials in Slovenia?

Jurij SENEGAČNIK

Classification of regional and thematic approaches in school textbooks on the geography of Europe

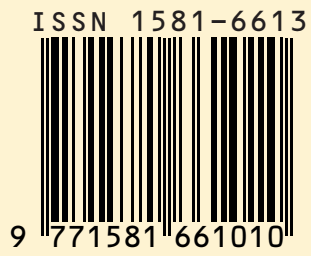




\section{ACTA GEOGRAPHICA SLOVENICA}

$58-2$

2018

ISSN: 1581-6613

COBISS: 124775936

UDC/UDK: 91

(C) Geografski inštitut Antona Melika ZRC SAZU 2018

International editorial board/mednarodni uredniški odbor: Michael Bründl (Switzerland), Rok Ciglič (Slovenia), Matej Gabrovec (Slovenia), Peter Jordan (Austria), Drago Kladnik (Slovenia), Blaž Komac (Slovenia), Andrej Kranjc (Slovenia), Dénes Lóczy (Hungary), Simon McCharty (United Kingdom), Slobodan Marković (Serbia), Milan Orožen Adamič (Slovenija), Drago Perko (Slovenia), Marjan Ravbar (Slovenia), Aleš Smrekar (Slovenia), Annett Steinführer (Germany), Mimi Urbanc (Slovenia), Matija Zorn (Slovenia).

Editor-in-Chief/glavni urednik: Blaž Komac; blaz@zrc-sazu.si

Executive editor/odgovorni urednik: Drago Perko; drago@zrc-sazu.si

Chief editor for physical geography/glavni urednik za fizično geografijo: Matija Zorn; matija.zorn@zrc-sazu.si Chief editor for human geography/glavna urednica za humano geografijo: Mimi Urbanc; mimi@zrc-sazu.si Chief editor for regional geography/glavni urednik za regionalno geografijo: Drago Kladnik; drago.kladnik@zrc-sazu.si Chief editor for spatial planning/glavni urednik za regionaln o planiranje: Janez Nared; janez.nared@zrc-sazu.si Chief editor for urban geography/glavni urednik za urbano geografijo: David Bole; david.bole@zrc-sazu.si Chief editor for geographic information systems/glavni urednik za geografske informacijske sisteme: Rok Ciglič; rok.ciglic@zrc-sazu.si

Chief editor for environmental protection/glavni urednik za varstvo okolja: Aleš Smrekar; ales.smrekar@zrc.sazu Editorial assistant/uredniški pomočnik: Matjaž Geršič; matjaz.gersic@zrc.sazu

Published by/izdajatelj: Geografski inštitut Antona Melika ZRC SAZU

Issued by/založnik: Založba ZRC

Co-issued by/sozaložnik: Slovenska akademija znanosti in umetnosti

Address/Naslov: Geografski inštitut Antona Melika ZRC SAZU, Gosposka ulica 13, SI - 1000 Ljubljana, Slovenija

The papers are available on-line/prispevki so dostopni na medmrežju:

http://ags.zrc-sazu.si (ISSN: 1581-8314)

Ordering/naročanje:

Založba ZRC

Novi trg 2, p. p. 306, SI - 1001 Ljubljana, Slovenija

Phone/telefon: $+386(0) 14706464$

Fax/faks: +386 (0)1 4257794

E-mail/e-pošta: zalozba@zrc-sazu.si

Annual subscription/letna naročnina: $20 €$ for individuals/za posameznike, $28 €$ for institutions/za ustanove. Single issue/cena posamezne številke: $12,50 €$ for individuals/za posameznike, $16 €$ for institutions/za ustanove.

Cartography/kartografija: Geografski inštitut Antona Melika ZRC SAZU

Translations/prevodi: DEKS, d. o.o.

DTP/prelom: SYNCOMP, d. o. o.

Printed by/tiskarna: Collegium Graphicum d. o. o.

Print run/naklada: 400 copies/izvodov

The journal is subsidized by the Slovenian Research Agency/revija izhaja s podporo Javne agencije za raziskovalno dejavnost Republike Slovenije.

The journal is indexed also in/revija je vključena tudi v: SCIE - Science citation index expanded, Scopus, JCR - Journal Citation Report/Science Edition, ERIH PLUS, GEOBASE Journals, Current geographical publications, EBSCOhost, Geoscience e-Journals, Georef, FRANCIS, SJR (SCImago Journal \& Country Rank), OCLC WorldCat, and Google scholar, CrossRef.

Front cover photography: Alpine environment has witnessed changes in discharge regimes that depend on the changes in precipitation and temperature regimes, land use and human influence (photograph: Matej Lipar).

Fotografija na naslovnici: Pretočni režimi se v alpskih pokrajinah spreminjajo zaradi sprememb v padavinskem in temperaturnem režimu ter sprememb rabe zemljišč in človeških vplivov (fotografija: Matej Lipar). 


\section{CLASSIFICATION OF REGIONAL AND THEMATIC APPROACHES IN SCHOOL TEXTBOOKS ON THE GEOGRAPHY OF EUROPE}

Jurij Senegačnik

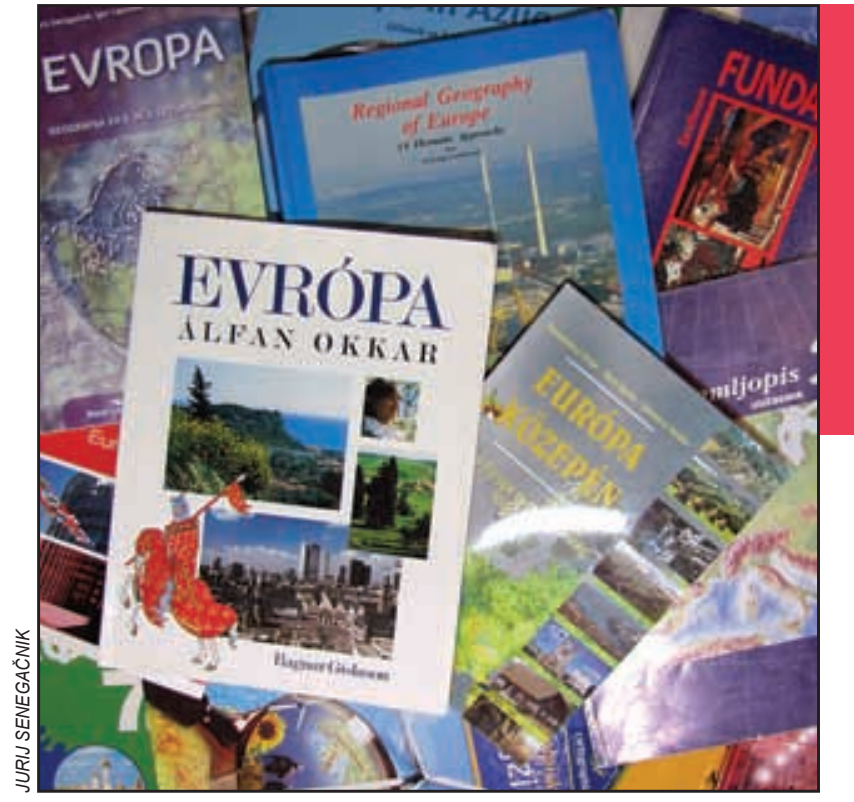

School textbooks of the geography of Europe from different European countries. 
DOI: https://doi.org/10.3986/AGS.3408

UDC: 91:37.091.64(4)

COBISS: 1.01

\title{
Classification of regional and thematic approaches in school textbooks on the geography of Europe
}

\begin{abstract}
Regional and thematic approaches are two basic approaches in geography, and they are found in many combinations and variants in textbooks. An extensive analysis of textbook approaches showed that a detailed classification of these approaches does not currently exist. The main purpose of this study was to fill this gap with the first attempt at a detailed classification of all possible approaches in European textbooks devoted in part or in full to examining the geography of Europe. To this end, it was also necessary to review the terminology and redefine some concepts. The study is based on an analysis of 450 textbooks from twenty-eight European countries using the method of content analysis. It resulted in four classification schemes: a scheme for geography in textbooks in general, and schemes for three approaches used in exploring the regional geography of Europe. Any European textbook covering the geography of Europe can be classified using these schemes.
\end{abstract}

KEY WORDS: regional geography, thematic geography, regional approach, thematic approach, textbook approaches, geography education, textbook, Europe

\section{Klasifikacija regionalnih in tematskih pristopov v šolskih učbenikih geografije Evrope}

POVZETEK: Regionalni in tematski pristop sta dva temeljna pristopa, ki izhajata iz sistema geografske vede, $\mathrm{v}$ učbenikih pa sta prisotna v številnih kombinacijah in različicah. Pri obsežni analizi učbeniških pristopov se je pokazalo, da ne obstaja nobena podrobna klasifikacija teh pristopov. Namen raziskave je bil zapolniti to vrzel s prvim poskusom podrobne klasifikacije vseh možnih pristopov, in sicer v evropskih učbenikih, ki so v celoti ali vsaj v velikem delu namenjeni obravnavi geografije Evrope. V ta namen je bilo treba pregledati terminologijo in na novo opredeliti nekatere pojme. Raziskava temelji na analizi 450 učbenikov iz 28 evropskih držav, pri čemer je bila uporabljena metoda vsebinske analize. Rezultat so štiri sheme: shema geografije $\mathrm{v}$ učbenikih na splošno ter sheme treh pristopov v okviru regionalne geografije Evrope, v katere je možno uvrstiti kateri koli evropski učbenik z obravnavo geografije Evrope.

KLJUČNE BESEDE: regionalna geografija, tematska geografija, regionalni pristop, tematski pristop, učbeniški pristopi, didaktika geografije, učbenik, Evropa

\section{Jurij Senegačnik}

Modrijan založba, d. o. o.

jure@modrijan.si

The paper was submitted for publication on September $1^{\text {st }}, 2015$.

Uredništvo je prejelo prispevek 1. septembra 2015. 


\section{Introduction}

The system of the geographical sciences is evident from many geographical encyclopedias that divide geography into general and regional geography. General geography focuses on a general overview of individual elements and factors on the Earth's surface, and regional geography explores individual parts of the Earth's surface (i.e., regions) as a whole. According to the International Charter on Geographical Education (Resnik Planinc 1993), school geography distinguishes between two approaches based on this division: thematic and regional. The thematic approach has primarily become established in school geography and, especially among US geographers, it is also used as a synonym for the systematic or general geography approach (Steinberg, Walter and Sherman-Morris 2002).

The analysis of textbook approaches used in European countries for examining the geography of Europe (Senegačnik 2005) showed that it does not make sense to categorize these approaches only into regional and thematic ones because textbooks largely use various combinations of these two approaches. A review of a large number of textbooks revealed a significant gap in the findings to date because the analysis could not rely on any detailed classification of regional and thematic textbook approaches. Considering that teachers prefer clearly structured textbooks and that the majority of them favor the regional approach (Senegačnik 2007a), a need arose to prepare an article to fill in this gap. Hence, this article is the first attempt at a detailed classification of all possible regional and thematic textbook approaches, resulting in four classification schemes that teachers can use as an effective tool in assessing and selecting textbooks.

\subsection{Terminology}

The term "approach « itself has several meanings. In the sense of a work method or a path to achieving something, it is used here in connection with teaching, curricula, and textbooks, whenever there is reference to the regional and thematic approach. The approaches used in textbooks are referred to here as »textbook approaches."

Even though general geography focuses on presenting all landscape elements and factors, in practice textbooks hardly ever cover all elements; instead, such a »classic « repertoire was gradually replaced by specialization in selected themes. According to Arnold Schultze (1970), textbooks focus only on certain key structures: natural structures, nature-human structures, functional structures, and sociocultural structures. Because these deviate from the classic general geography scheme, this approach later became known in Germany as the »thematic approach. "Although this term gradually also became used in other countries, the term »thematic geography« is still very rarely found in the literature today. Among the forty-one geographical dictionaries reviewed at the University of Ljubljana's Geography Department, this term can only be found in one (Lévy and Lussault 2003, 920).

Based on the development described above, the following definitions were established: "general geography« or the "general geography approach « refers to the systematic presentation of all elements and factors known from the »sections « of general geography and, following Arnold Schultze's theory of key structures (1970), »thematic geography« or the »thematic (geography) approach« is conceived as a non-systematic presentation of selected elements and factors.

Such a definition is deficient with regard to the term "geographical themes « because their selection in textbooks became increasingly diverse. This approach is usually primarily understood in the sense of examining themes from »non-systematic « or »extended « general geography and significantly less in the sense of examining themes in order to present specific regions, which is the focal point of regional geography or the regional approach.

It is impossible to draw a clear line between general and thematic geography in textbooks. The term »thematic geography « is not an entirely unambiguous and clearly definable category because it can be conceived either in a broader or narrower sense. "Thematic geography in the broadest sense « is composed of "general geography" and "thematic geography (in the narrower sense). "General geography is basically systematic thematic geography (a systematic presentation of more or less all general geography elements). It can also be referred to as "thematic geography in the broader sense « because it deals with themes just like thematic geography; the only difference is that it covers "all " general geography themes, not just selected ones. On the other hand, there is "thematic geography in the narrow sense, " which only examines selected themes - which at least in the initial stages of thematic geography proceeded from Schultze's key structures 
- and can therefore be referred to as »non-systematic thematic geography.« Under »thematic geography» school geographers mostly understand only the latter. Unlike thematic geography, »regional geography» focuses on a complex presentation of a specific region. This definition still unambiguously applied to classic regional geography during Alfred Hettner's time, but later on, due to too much material involved in presenting regions as a "whole, « textbooks started increasingly limiting themselves to presenting selected key themes and, later on, central problems. Nonetheless, such geography continued to be referred to as "regional geography« because the region remained the basic subject of its presentation.

\subsection{Historical development of approaches}

Until the mid-twentieth century, the leading international school in geography was the German geographical school, which was distinctly oriented towards regional geography. One of its most important representatives was Alfred Hettner, and the main transmitter of his ideas to US geography was Richard Hartshorne (1939). During the 1950s, a conflict arose among US geographers - specifically, between the advocates of the traditional regional approach and the adherents of the "new « geography, which placed general geography at the forefront. The most important representative of the second group was Fred K. Schaefer (1953). The controversy between the two camps continued for several years, but in the US the breach between them was not as severe as later on in Germany. The majority of geographers thought of both approaches as complementary, which was later also reflected in the project of national geography education standards (Bednarz et al. 1994), which included both.

University textbooks for courses in world geography played an extremely important role in US geography (Muller 1995). Their authors combined both approaches, presenting the world by world regions (i.e., in line with regional geography) and then examining each region using the thematic approach (Steinberg, Walter and Sherman-Morris 2002). The system of the geographical sciences is still evident from these textbooks because it is a combination of both approaches. The best-known works include those by Harm de Blij and Peter Muller (2013), Lydia Mihelič Pulsipher and Alex Pulsipher (2013), Michael J. Bradshaw et al. (2012), and Lester Rowntree et al. (2013). Cadey Korson and Weronika Kusek (2015) report that as many as $75 \%$ of instructors teaching world geography at US universities use the regional approach, $20 \%$ use the thematic approach, and $12.5 \%$ use a combination of both.

In Germany, the breach between the proponents of regional and general geography at a congress in Kiel in 1969 was even more severe than it had been in the US. The main supporter of regional geography was Josef Birkenhauer (1970) and the main adherent of general geography was Arnold Schultze (1970). A few years later, an attempt at a compromise in the form of general geography in regional classification was made by Jürgen Newig, Karl Heinz Reinhardt, and Peter Fischer (1983). This breach, which has never really been entirely resolved, was also reflected in the school curricula (Brucker 2009). They sought to include elements of both approaches, but in some of them the framework of the system of the geographical sciences could hardly be discerned any more.

In Slovenia, the regional approach predominated in school geography. The advantages of the thematic approach were substantiated by Sabina Popit (2002) and the advantages of the regional approach were presented by Jurij Senegačnik (2003b; 2005; 2007a).

The Slovenian geographer Anton Melik (1935) first treated Slovenia as a whole by individual general geography sections, followed by Slovenian regions (Melik 1954, 1957; 1959; 1960). In two seminal works published after Slovenia's independence, geographers treated Slovenia both according to individual sections of general geography (Gams and Vrišer 1998) and by individual regions (Perko and Orožen Adamič 1998).

In this regard, the question arises whether all of these works on Slovenia involve regional geography or perhaps a different type of geography. Even the two works that examine Slovenia by individual sections of general geography (Melik 1935; Gams and Vrišer 1998) namely present a region: Slovenia. This means they are part of regional geography and can thus be referred to as regional geography works, even though they use a different approach than other works.

The approach used by Anton Melik (1935) and Ivan Gams and Igor Vrišer (1998) can be referred to as a "general geography« approach (the general geography of Slovenia), even though it examines geographical elements and factors only in one region (i.e., Slovenia) and not around the entire world. Hence, this involves a regional geography of Slovenia, even though the approach used is that of general geography. In this case, one can speak of a "general-geography regional geography» (of Slovenia). 
Other works (Melik 1954; 1957; 1959; 1950; Perko and Orožen Adamič 1998) present Slovenian regions. They also involve a regional geography of Slovenia, but the approach they use differs significantly. Their purpose is not to examine elements and factors across all of Slovenia, but to present individual regions in a comprehensive manner. Because this approach focuses on individual regions rather than individual elements and factors (in Slovenia as a whole), it can be referred to as a »region-based approach.«In this case, one can talk about a »region-based regional geography (of Slovenia) « or a »regional geography of (Slovenian) regions."

\subsection{Using individual approaches in textbooks}

Textbooks on the geography of Slovenia for primary schools are a combination of either a) a general-geography and region-based regional geography of Slovenia, or b) a general geography and region-based approach. They thus use a "combined (general-geography and region-based) approach." Even though as much as half of a given textbook uses a general geography approach (i.e., it focuses on the general geography of Slovenia) and only half uses a region-based approach (i.e., it focuses on the regional geography of Slovenian regions), this is predominantly perceived as a regional approach.

The same parallels in Slovenian textbooks can also be found with regard to the presentation of the geography of Europe, where part of a textbook uses a general geography approach (the general geography of Europe) and part of it uses a region-based approach (the region-based geography of Europe or the geography of European regions).

Looking at how textbooks in other European countries cover Europe, whereby the entire textbook can be dedicated to Europe or only a larger or small part of it (which is mostly the case), many parallels can be drawn, but certain different approaches can be found as well. In these textbooks, the general geography part of examining Europe is largely replaced by the thematic geography approach because, as a rule, they stopped using the systematic approach of general geography and limited themselves to a non-systematic selection of specific themes. Thus the combined approaches largely no longer use a combination of the general geography and region-based regional geography, but a combination of a thematic (in the narrow sense) and region-based regional geography, or a »combined (thematic region-based) regional approach.»

There are also textbooks that use only the region-based approach (they examine Europe by regions) as well as textbooks that use an intermediate approach, which includes a non-systematic combination or mix of region-based and thematic regional geography.

Many geography textbooks contain a few paragraphs of text, maps, graphs, and figures that refer to a specific learning theme from the geography of Europe, but this does not mean they are dedicated to the regional geography of Europe. In order to establish whether a textbook is dedicated to the regional geography of Europe or not, its content must be examined because this can rarely be determined from its title alone. Among the 450 textbooks analyzed, only a third met the criterion that was set to prove that a textbook involved a regional geography of Europe. This included any examination of the geography of Europe, in which all of Europe or at least a major portion of it received special coverage in the form of a longer whole (a textbook as a whole or part of a textbook in the form of one or several conceptually complete chapters). The final criterion for the existence of such a »regional « geography of Europe in a textbook is that the title of a specific whole already indicates that the concrete region of Europe is at the forefront of the discussion, and not one or several themes from thematic or general geography. In this context, regional geography is naturally understood in its broadest possible theoretical sense.

For example, the Austrian textbook Planquadrat Erde (Klappacher, Fischer and Fischer 2002) explores a series of thematic sections titled »People and the Environment, «»Revaluation of Space, «»Good Old Europe, « and so on, in which only the last deals with Europe and combines several completely social themes. Thus, it discusses Europe as a »theme" and not as a »region. "Despite reservations, such a thematic section or such a chapter in the textbook was treated as a regional geography of Europe because it is clear that the main subject discussed is Europe (even though only through certain themes selected) rather than geographical themes in general.

This can also be viewed from a different perspective. If the determination of the "regional « or »thematic « character of textbooks is based on the reflections of the three German geographers mentioned above (Newig, Reinhardt and Fischer 1983), which proceed from strictly didactic premises, the chapter "Good Old Europe " merely involves a »thematic geography in a regional classification « or a »thematic geography 
with a regionally defined title« rather than "proper « regional geography. According to the same logic, other titles, such as »People and the Environment« and »Revaluation of Space« represent »thematic geography in a thematic classification " or a »thematic geography with thematically defined titles."

The overview of works on both approaches published to date shows that they primarily focused on the theoretical advantages of one or the other in geography in general, the frequency of their use at universities, and the inclusion of both in the curricula (Rinschede 2003). The authors mostly did use concrete empirical studies to support their opinions on the advantages of one or the other and merely based them on their own theoretical reflection. Because the majority of articles to date have not focused directly on the use of both approaches in school textbooks, this issue has remained fairly understudied.

Another problem arose while preparing the classification: the terminology used in this area to date has been very incomplete and vague. Therefore, the existing terminological concepts useful for this classification had to be collected from the literature and organized, after which appropriate new definitions had to be provided for the missing ones. With regard to this terminology, a great deal had previously been achieved by German educators (Köck 1986; Sperling 1990; Böhn 1999; Rinschede 2003; Böhn and Obermaier 2013), who named and defined various approaches; however, they only did that in the curricula and not in the textbooks as well. The German definitions were adapted to the Slovenian context by Senegačnik (2007b). This study therefore has a double goal: to prepare a new classification of the textbook approaches mentioned above and appropriate (and partly new) terminology.

\section{Methods}

The classification of approaches was made based on the analysis of school textbooks on the regional geography of Europe for all age levels from twenty-eight European countries. To this end, 450 textbooks, in which at least some of the content was connected with this continent, were reviewed. Only a third of the textbooks were exclusively dedicated to the regional geography of Europe. Detailed criteria for the selection of the textbooks are presented in Section 1.3. Work was carried out at the library of the Georg Eckert Institute in Braunschweig. This study can be ranked among non-experimental empirical educational studies. It used a descriptive method, which makes it possible to explore the educational field using the question of what something looks like and also how much of it there is (Sagadin 1993). According to Mužić (1982), the method applied can be defined as a comparative textbook analysis. The present study involves a horizontal analysis because it includes textbooks for the same school subject from different geographical areas. Textbook analysis developed into a special discipline called »textbook research« (Pingel 1999). Mikk (2000) defines textbook analysis as collecting data on the textbook characteristics that contribute to the realization of textbook functions. This study is a type of qualitative study (Montello and Sutton 2013; Remler and Ryzin 2015). It was carried out using the method of content analysis, which already began being established before the Second World War, especially in the social sciences (Hard 1978; Weinbrenner 1998; Neuendorf 2002; Mejovšek 2003; Senegačnik 2003a; Elo and Kyngäs 2008; Coolican 2014; Komac, Zorn and Ciglič 2011; Geršič 2014). These authors do not share exactly the same views on what can be classified under the content analysis method. Urbanc (2008) reports that this method is often confused with the grounded theory method.

Work proceeded as follows: with every textbook analyzed, it was first checked whether the entire textbook or only part of it was dedicated to the regional geography of Europe. After this, it was established whether the textbook used a thematic or regional approach or a combination of both. The textbook or the part covering Europe was divided into conceptually complete wholes in terms of whether these component parts examined Europe by themes or regions. The component parts that examined Europe by regions were logically divided into two parts: a thematic introduction to a specific region and the examination of its parts.

In the next research stage, all of the textbook component parts obtained were combined into more abstract categories, based on which individual approaches (i.e., regional or thematic) were defined. In this way, a classification of these approaches was gradually created and, as the number of textbooks analyzed grew, the classification was added to on an ongoing basis. With regard to regional approaches, three categories were isolated and divided into several subcategories of various levels according to the method of examining regions (by theme, country, case study, etc.). In the end, the study resulted in four approach schemes. 


\section{Results}

Several schemes with a detailed classification of regional and thematic textbook approaches were created. The first scheme presents the scheme of geography (i.e., the system of the geographical sciences and its basic approaches) in European textbooks in general. This includes all textbooks with any content, not only those covering Europe. If several dozen randomly selected textbooks are examined, one can distinguish between three versions (Figure 1).

1) The first group includes »textbooks covering only thematic geography (in its broadest sense). This means they deal with both systematic and non-systematic thematic geography, but they do not examine a specific region as a special "theme" because that would already imply regional geography. (From the educational perspective, this version involves thematic geography in a thematic classification.) These types of textbooks can examine "general geography (systematic thematic geography or thematic geography in the broader sense) or "thematic geography (non-systematic thematic geography or thematic geography in the narrow sense). In the first case, they use a "general geography approach " and in the second they use a »thematic geography approach.«

2) The second group includes textbooks that only cover »regional geography (in the broadest sense). (From the educational perspective, this also includes thematic geography in a regional classification in addition to "proper " regional geography.) These types of textbooks can examine one or more regions or parts of the world (a home country, Europe, several continents). Regional geography in this case refers to the examination of those complete conceptual wholes, in which the titles already indicate that one or more regions are at the forefront of discussion rather than various geographical elements and factors. In principle, four approaches can be used for examining every region.

The first one is the »thematic or thematic geography approach « (as part of thematic regional geography). Every region (e.g., home country, Europe) is examined as a whole, but only by individual themes rather than smaller regions. The other three approaches labeled »regional (regional geography) approaches« examine every region also or exclusively by (smaller) regions. Among these, one can distinguish between the

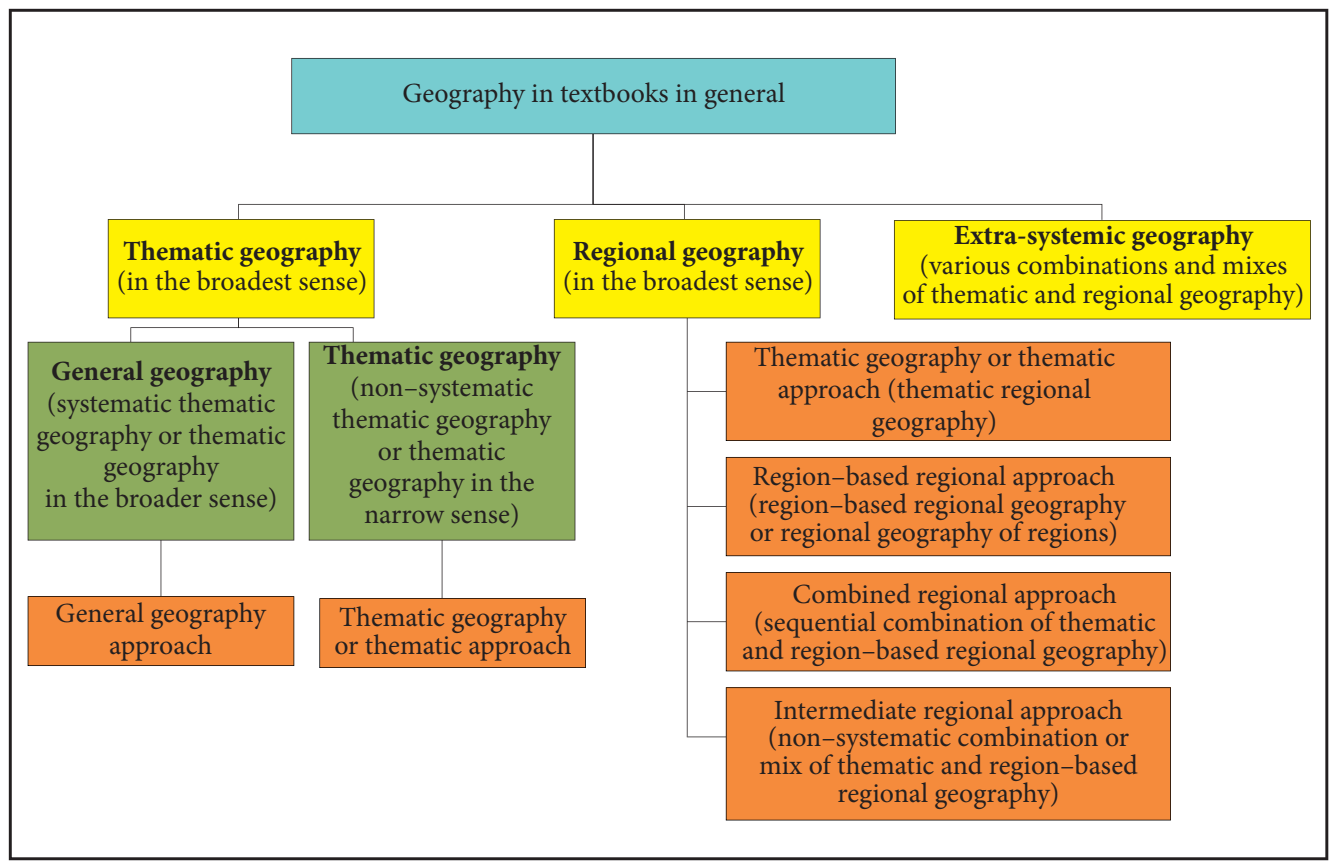

Figure 1: Geography or the system of the geographical sciences in terms of its regional or thematic approach in textbooks in general. 
»region-based regional approach« (derived from the region-based regional geography or regional geography of regions), the »combined regional approach« (a sequential combination of thematic and region-based regional geography), and the »intermediate regional approach « (non-systematic combination or mix of thematic and region-based regional geography). This scheme is difficult to understand primarily because regional geography cannot be equated with the regional approach; instead, there is regional geography with a thematic approach on the one hand, and regional geography with various regional approaches on the other. 3) The third group includes textbooks from which the system of the geographical sciences is very difficult to determine or can no longer be clearly determined because they use »various combinations and mixes of thematic and regional geography." Because such textbooks somehow extend beyond geography, this can be referred to as "extra-systemic geography. « Within its framework, the possible versions of approaches cannot be analyzed because they are simply outside the system studied.

The other three schemes present a detailed classification of approaches used in the textbooks of various European countries that cover the regional geography of Europe. In these schemes, various versions of the three approaches mentioned above (one thematic and two regional) were analyzed; for the third regional approach (i.e., the intermediate approach) the possible versions are not listed because there are too many.

The first one is the "thematic or thematic geography approach as part of the regional geography of Europe « (Figure 2). Even though it has the same name, it must not be confused with the thematic approach as part of thematic geography. The thematic approach as part of regional geography derives from thematic regional geography in the broadest sense. This is not a regional approach, even though it is being used in regional geography. It can be divided into the "general geography approach « (a systematic thematic approach or a thematic approach in the broader sense), which derives from general geography regional geography, and the "thematic geography or thematic approach « (a non-systematic thematic approach or a thematic approach in the narrow sense), which derives from thematic regional geography in the narrow sense.

This approach examines the learning material by smaller conceptual wholes, which can be referred to as »learning themes, « among which one can distinguish between more general or »common « themes, more "concrete" case studies, and combinations of a thematic "introduction " and one or more concrete case studies. It is very difficult or even impossible to draw a clear line between a "common « theme and a case study, and therefore it would make sense to further divide both approaches into approaches that examine material predominantly by themes and approaches that examine material predominantly by case studies.

The "region-based regional approach « (Figure 3 ) is the second possible approach in regional geography (of Europe) and at the same time the first of the three regional approaches. This approach is the most regional because it does not include a general or thematic introduction to Europe as a whole, but only examines its regions. It thus derives from region-based regional geography or the regional geography of regions. It can be divided into a »simple region-based approach « (without introductions to individual regions) and

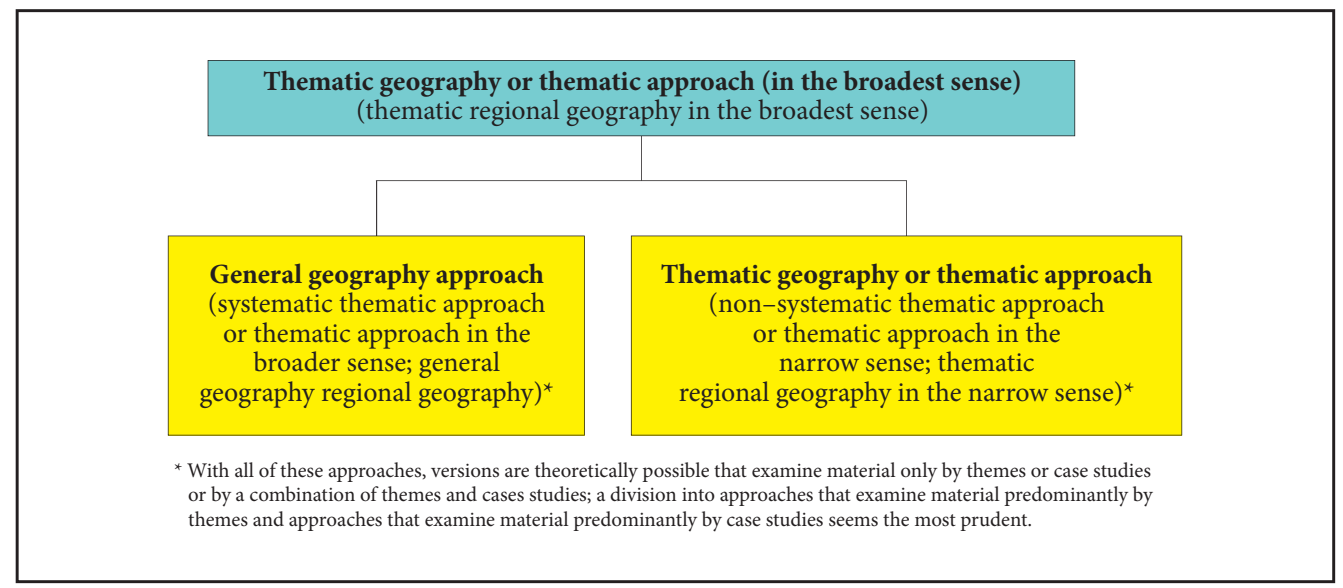

Figure 2: The thematic geography approach in the broadest sense as part of the regional geography of Europe. 
a »combined region-based approach; « the latter can be further divided into a version with a non-systematic introduction and a version with a systematic introduction to an individual region. With both the simple and combined region-based approach and its two versions, one can distinguish between five versions of possible examination of European regions; they are numbered 1 to 5 in Figure 3.

The most complex and also the most frequently used approach is the "combined (thematic region-based) regional approach, « which allows a large number of different versions (Figure 4). It includes a combination of thematic and region-based regional geography, in which one can distinguish between a »once-combined « or »twice-combined « approach. (They could also be referred to as a simple and composite combined approach.) Each version is further divided into a version "with a systematic (general geography) introduction to Europe" and a version "with a non-systematic (thematic geography) introduction to Europe. "The former includes more or less classic themes from general geography, which are largely social. The thematic or general geography part of the examination of Europe, referred to here as an »introduction « to Europe, sometimes comes after the regional part of the examination and not before it.

With the twice-combined approach, the combination of thematic or general and region-based regional geography also repeats in the examination of individual regions because one can further distinguish between a version "with a systematic introduction " and a version "with a non-systematic introduction to an individual region. « Every examination of individual European regions can entail one of the five possible versions, which are numbered 1 to 5 in Figure 4. Specifically, individual regions can be examined by non-selected themes from general geography, by selected themes, by non-selected countries, by selected countries, and by selected themes and countries. There is practically no approach that would examine everything about each and every country, although some textbooks still try to achieve this. In addition, it is also possible to include case studies in various combinations with individual themes or countries, which naturally increases the final number of possible combinations.

\section{Discussion}

The main result of this study (i.e., classification in the form of four schemes) fills the large research gap in the current findings on regional and thematic textbook approaches. The analysis of these textbook approaches showed that no detailed classification was currently available, and so a new one had to be produced.

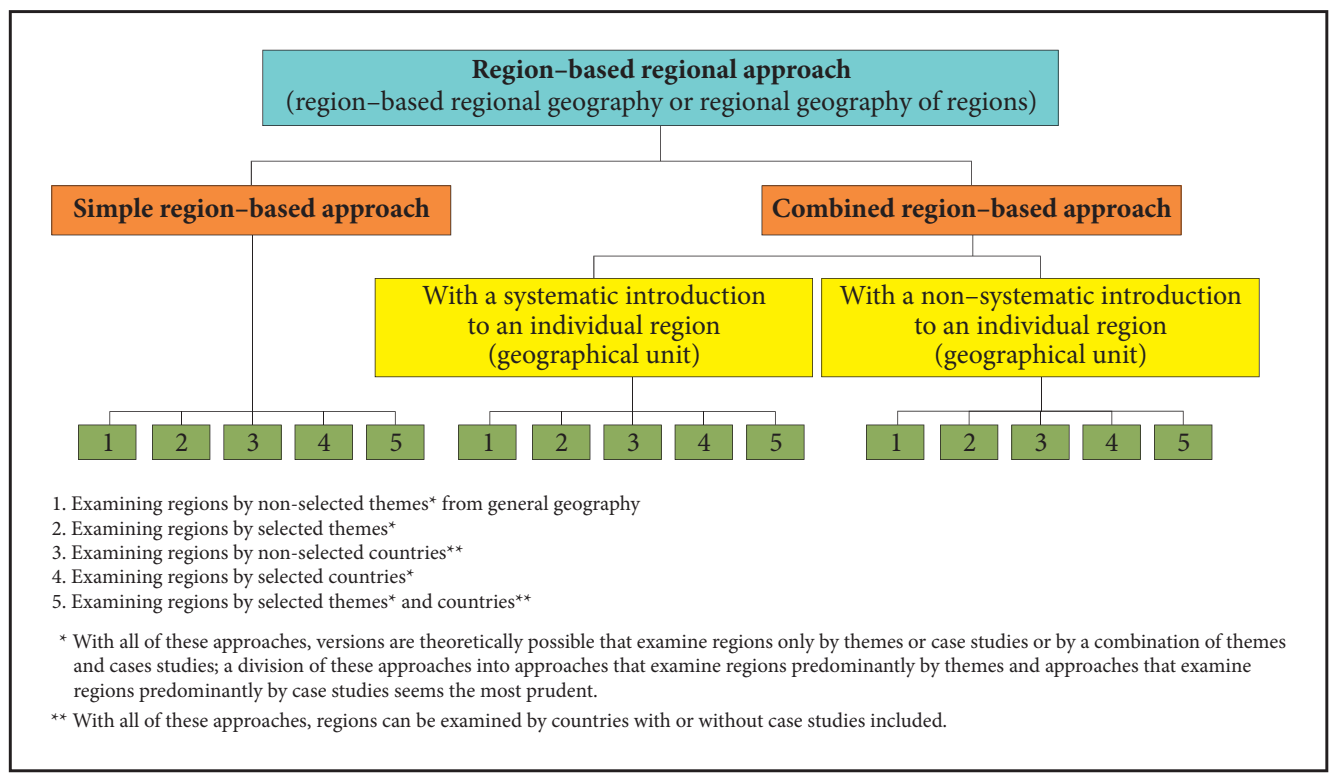

Figure 3: The region-based regional approach as part of the regional geography of Europe. 


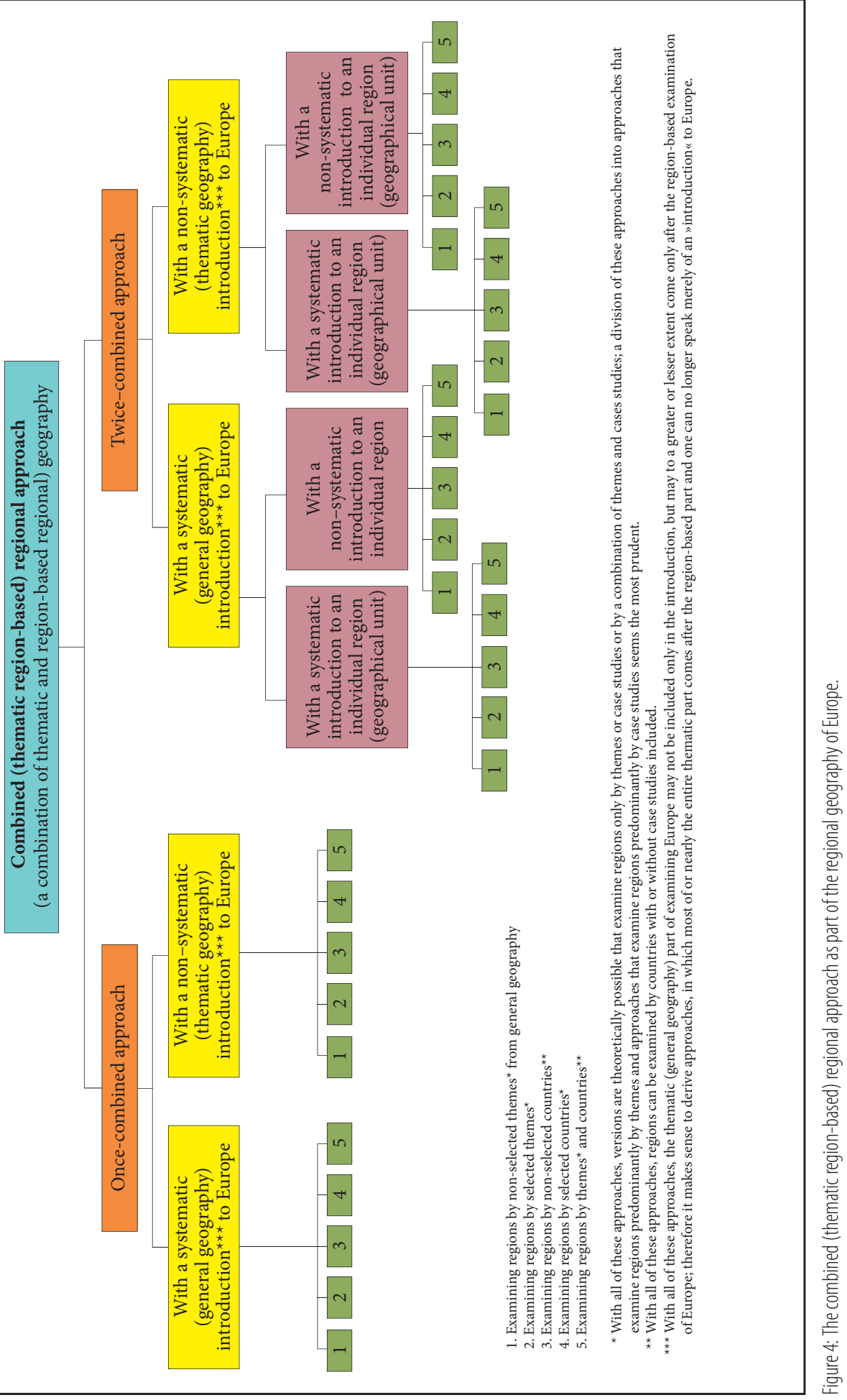


The analysis of all possible regional and thematic textbook approaches proved to be significantly more complex than might be expected based on the previous studies. As a rule, these were limited to the use of two basic approaches, failing to also take into account the numerous combinations and versions that can in fact be found in the textbooks. Somewhat greater efforts to analyze these approaches in more detail were only made by German geography educators, but they were limited to the level of the curricula. Their definitions thus do not extend as deeply into the research issue as the classification presented in this study.

Another important result of this study was the preparation of appropriate terminology, which partly had to be formulated anew. The newly defined terms included extra-systemic geography, a region-based regional approach, region-based regional geography, and so on.

The study has also yielded some unexpected results. It turned out that textbook authors follow the system of the geographical sciences to a much lesser extent than initially expected, and that by using a combination of both basic approaches they created a significantly larger number of possible versions than initially anticipated.

\section{Conclusion}

The main value of this study does not lie in important empirical results, but first and foremost in its contribution to the theory of geography or the system of the geographical sciences, and to geography textbook theory. The basic research goal was to prepare the first detailed classification of all possible regional and thematic textbook approaches using the examples of European textbooks covering the regional geography of Europe, while also solving the issue of lacking terminology. The main result of this study is four classification schemes derived from the system of the geographical sciences. The first one is the scheme for geography in textbooks in general, where one can distinguish between thematic geography (in the broadest sense), regional geography (in the broadest sense), and extra-systemic geography. This is followed by the schemes for three approaches used for covering the regional geography of Europe: one thematic and two regional. The two regional approaches include the region-based regional approach and the combined (thematic-regional) regional approach.

The study was limited to textbooks covering the regional geography of Europe, and so it would make sense to repeat it using textbooks with different content (e.g., examining the home country) and interpret the results quantitatively as well. The classification produced can be used by teachers as an effective instrument for analyzing and evaluating textbooks and selecting the best ones for use in the classroom.

\section{References}

Bednarz, S. W., Bettis, N. C., Boehm, R. G., de Souza, A. R., Downs, R. M., Marran, J. F., Morrill, R. W., Salter, C. L. 1994: Geography for life: national geography standards 1994. Washington.

Birkenhauer, J. 1970: Die Länderkunde ist tot. Es lebe die Länderkunde. Geographische Rundschau 22-1. De Blij, H. J., Muller, P. O. 2013: Geography: Realms, Regions and Concepts. Hoboken.

Böhn, D. 1999: Didaktik der Geographie: Begriffe. München.

Böhn, D., Obermaier, G. 2013: Wörterbuch der Geographiedidaktik. Begriffe von A - Z. Braunschweig. Bradshaw, M., White, G. W., Dymond, J. P., Chacko, E. 2012: Contemporary World Regional geography. New York.

Brucker, A. (ed.) 2009: Geographiedidaktik in Übersichten. Köln.

Coolican, H. 2014: Research Methods and Statistics in Psychology. London, New York.

De Blij, H. J., Muller, P. O. 2013: Geography: realms, regions and concepts. Hoboken.

Elo, S., Kyngäs, H. 2008: The qualitative content analysis process. Journal of Advanced Nursing 62/1. DOI: https://doi.org/10.1111/j.1365-2648.2007.04569.x

Gams, I., Vrišer, I. 1998: Geografija Slovenije. Ljubljana.

Geršič, M. 2014: Obravnava geografije kot znanosti pri pouku v osnovni šoli. Geografski vestnik 86-1. DOI: https://doi.org/10.3986/GV86102

Hard, G. 1978: Inhaltsanalyse geographiedidaktischer Texte. Geographiedidaktische Forschungen Band 2. Braunschweig. 
Hartshorne, R. 1939: The nature of geography: A critical survey of current thought in the light of the past. Annals of the Association of American Geographers 29.

Klappacher, O., Fischer, I., Fischer, R. 2002: Planquadrat Erde. Geographie und Wirtschaftskunde 4. Lehrund Arbeitsbuch für die 12. Schulstufe. Linz.

Köck, H. (ed.) 1986: Grundlagen des Geographieunterrichts. Handbuch des Geographieunterrichts 1. Köln.

Komac, B., Zorn, M., Ciglič, R. 2011: Izobraževanje o naravnih nesrečah v Evropi. Georitem 18. Ljubljana.

Korson, C., Kusek, W. 2015: The Comparison of a Thematic versus Regional Approach to Teaching a World Geography Course. Journal of Geography 115-4. DOI: http://dx.doi.org/10.1080/00221341.2015.1076498

Lévy, J., Lussault, M. 2003: Dictionnaire de la géographie et de l'espace des sociétés. Paris.

Mejovšek, M. 2003: Uvod u metode znanstvenog istraživanja u društvenim i humanističkim znanostima. Jastrebarsko.

Melik, A. 1935: Slovenija - geografski opis. Ljubljana.

Melik, A. 1954: Slovenski alpski svet. Ljubljana.

Melik, A. 1957: Štajerska s Prekmurjem in Mežiško dolino. Ljubljana.

Melik, A. 1959: Posavska Slovenija. Ljubljana.

Melik, A. 1960: Slovensko Primorje. Ljubljana.

Mihelič Pulsipher, L., Pulsipher, A. 2013: World regional geography. New York.

Mikk, J. 2000: Textbook: research and writing. Frankfurt am Main.

Montello, D. R., Sutton, P. C. 2013: An introduction to scientific research methods in geography \& enviromental studies. London, Thousand Oaks, New Delhi, Singapore.

Muller, P. O. 1995: The contribution of textbooks to undergraduate geography instruction in the USA. Journal of Geography in Higher Education 19-3. DOI: https://doi.org/10.1080/03098269508709330

Mužić, V. 1982: Metodologija pedagoškog istraživanja. Sarajevo.

Neuendorf, K. A. 2002: The content analysis guidebook. Thousand Oaks, London, New Delhi.

Newig, J., Reinhardt., K., Fischer, P., 1983: Allgemeine Geographie am regionalen Faden. Diskussionspapier für ein neues Konzept das Faches Erdkunde. Geographische Rundschau 35-1.

Perko, D., Orožen Adamič, M. (eds.) 1998: Slovenija - pokrajine in ljudje. Ljubljana.

Pingel, F. 1999: UNESCO Guidebook on textbook research and textbook revison. Hannover.

Popit, S. 2002: Vrednotenje dodiplomskega izobraževanja učiteljev geografije z vidika njene paradigmatične zgradbe. Doktorska disertacija, Filozofska fakulteta Univerze v Ljubljani. Ljubljana.

Remler, D. K., Van Ryzin, G. G. 2015: Research methods in practice. Strategies for description and causation. Los Angeles, London, New Delhi, Singapore, Washington.

Resnik Planinc, T. 1993: Mednarodna listina o geografskem izobraževanju. Geografija v šoli 3.

Rinschede, G. 2003: Geographiedidaktik. Padeborn.

Rowntree, L., Lewis, M., Price, M., Wyckoff, W. 2013: Globalization and diversity: geography of a changing World. Upper Saddle River.

Sagadin, J. 1993: Poglavja iz metodologije pedagoškega raziskovanja. Ljubljana.

Schaefer, F. 1953: Exceptionalism in geography: A methodological examination. Annals of the Association of American Geographers 43-3.

Schultze, A. 1970: Allgemeine Geographie statt Länderkunde. Geographische Rundchau 22-1.

Senegačnik, J. 2003a: Prikaz Slovenije v osnovnošolskih učbenikih geografije Evrope na območju nekdanje Jugoslavije. Geografski vestnik 75-2.

Senegačnik, J. 2003b: Regionalni in tematski pristop v gimnazijskem programu na primeru učbenika geografije Evrope. Geografija v šoli 12-3.

Senegačnik, J. 2005: Geografija Evrope v šolskih učbenikih evropskih držav. Doktorska disertacija. Filozofska fakulteta Univerze v Ljubljani. Ljubljana.

Senegačnik, J. 2007a: Regional or thematic? Preferences in basic textbook approaches to the study of geography in Slovenian secondary schools. Internationale Schulbuchforschung 29-1.

Senegačnik, J. 2007b: Opredelitve pristopov v nemški šolski geografiji. Geografija v šoli 16-1.

Sperling, W. 1990: Grundbegriffe landeskundlichen Denkens. Praxis Geographie 20-4.

Steinberg, P. E., Walter, A., Sherman-Morris, K. 2002: Using the internet to integrate thematic and regional approaches in geographical education. The Professional Geographer 54-3. DOI: https://doi.org/10.1111/0033-0124.00334

Urbanc, M. 2008: Raba utemeljevalne teorije in programa ATLAS.ti v geografiji. Geografski vestnik 80-1.

Weinbrenner, U. C., 1998: Erziehung zu europäischer Solidarität durch geographische Schulbücher der Sekundarstuffe 1. Eine quantitative und qualitative Inhaltsanalyse. Nürnberg. 